\title{
Innovation in Healthcare Performance among Private Brand's Healthcare Services in Small and Medium-sized Enterprises (SMEs)
}

\author{
Rohaizat Baharun ${ }^{1}$, Tock Jing $\mathrm{Mi}^{2}$, Dalia Streimikiene ${ }^{3}$, Abbas \\ Mardani $^{4}$, Jawaria Shakeel ${ }^{5,6}$, Vitalii Nitsenko ${ }^{7}$ \\ ${ }^{1}$ Azman Hashim International Business School, Universiti Teknologi Malaysia, \\ 81310 Johor Bahru, Johor, Malaysia, E-mail: m-rohaizat@utm.my \\ ${ }^{2}$ Azman Hashim International Business School, Universiti Teknologi Malaysia, \\ 81310 Johor Bahru, Johor, Malaysia \\ ${ }^{3}$ Vilnius University, Kaunas Faculty, Muitines 8, Kaunas, LT-42280, Lithuania, \\ E-mail: dalia.streimikiene@khf.vu.lt \\ ${ }^{4}$ Azman Hashim International Business School, Universiti Teknologi Malaysia, \\ 81310 Johor Bahru, Johor, Malaysia, E-mail: mabbas3@live.utm.my \\ ${ }^{5}$ Azman Hashim International Business School, Universiti Teknologi Malaysia, \\ 81310 Johor Bahru, Johor, Malaysia, E-mail: sjawaria@graduate.utm.my \\ ${ }^{6}$ COMSATS University Islamabad, 5400, Lahore Campus, Pakistan, E-mail: \\ jawaria@cuilahore.edu.pk \\ ${ }^{7}$ Department of Accounting, Analysis and Audit, Odessa I. I. Mechnikov National \\ University, Odessa, Ukraine
}

\begin{abstract}
Small and medium-sized enterprises (SMEs) in Malaysia are rapidly expanding their businesses; they use international diversification as an imperative strategic route to attain growth. Due to the great potential of SME in a developing market and the importance of branding that induces the performance of a company, there is a need for more research to explore branding dimensions. This research is mainly aimed at empirically examining the interrelated relationships that exist among various SME branding constructs (i.e., brand orientation, brand trust, brand equity, innovation, SME performance, marketing, and financial performance) and testing whether the proposed SME branding dimensions model efficiently helps us to understand the role the SME branding plays in growth and success of a firm. The research adopts a combination of qualitative and quantitative approaches, known as mixed model method. A sample containing 67 items of data was collected from a healthcare center, involving the owner, health specialists, and customers. This study aims to contribute to new marketing knowledge on the area of healthcare branding in SMEs, and identify the branding dimensions that affect the financial and marketing performance of small and medium sized enterprises. The results of this study found that a good brand orientation is the most important component that contributes to the healthcare performance.
\end{abstract}

Keywords: Brand equity; Brand trust; Innovation; Healthcare; SME's Performance 


\section{Introduction}

Brand management has been mentioned extensively in the marketing literature since decades ago and its strategic importance to a company has been well recognized $[15,39,47]$. Past studies have suggested that companies that direct their managerial activities and practices in the direction of the expansion, procurement, and leveraging of branded products and services are in a better position to improve their performance $[33,57]$. Though, previous researchers have linked several branding determinants with the company performance in SMEs [11, $22,25,52,64,69]$. Those studies are usually focused on SME in the manufacturing field, neglecting the application of branding in services industry, e.g., the healthcare services. Only a small number of researchers in the field of branding have focused on smaller units such as dental, clinics, and maternity centers. Additionally, according to Barbis [9], the literature available on the healthcare topic is very limited. From a larger perspective, brand literature has mainly focused on international large-scale industries only. Hence. Neglecting the enterprises of small and medium size [5, 14, 25]. Another limitation is that the majority of companies studied have been from the western and eastern developed countries only (see Inter-brand). Thus, plenty of work is required for a neglected country like Malaysia. The SMEs branding studies in Malaysia suffers from a lack of consensus, since there are several different streams that are contradictory to each other and have little, or nothing, that links branding, SME, and performance together [6].

One of the most powerful and important asset that each company needs to have is brand equity [1]. Based on the study conducted by Piaralal and Mei [58], building brand equity in healthcare sector is not an easy task. However, it should be delivered consistently within the center because it ensures quality assurance; this is what most customers seek when it comes to wellness services. On the other side, Schindehutte et al. [62] stated that the illustration of innovation is about reconfiguring, realigning, and renewing the marketing activities within a planned progression and development in spite of dramatic transformation. Innovation is one of the driving forces in defining effective strategy for SMEs. Innovativeness helps companies to see the significance of implementing branding [61] as an essential instrument to be well adopted to innovative services that meet consumer demands; this is because a strong brand gives credibility and security [1]. However, the stricter national policies on healthcare branding have put additional pressures on privately owned centers such as clinics and pharmacies (see The Medicine (Advertisement and Sale) Act 1956 and Malaysian Health Promotion Board Act 2006). For example, according to The Medicine (Advertisement and Sale) Act 1956, Section 3 to Section 4A, all advertisement related to medicines, diseases, skills, and services are prohibited. No one person is allowed to be involved in publishing any advertisement referring to any medicine, an appliance, or a remedy except those published by the Federal or State Government. The major gap to the marketing literature is limited branding studies on small and 
medium sized enterprises, which is considered comparatively new in Malaysia's [6] healthcare centers. In fact, Malaysia generally lacks research on branding, which is due to the managers' and owners' ignorance of branding practice. As literature shows, most of the studies in this field are conducted by Western scholars $[14,25,42,52]$.

This study is aimed at providing empirical evidence in the related area by developing a model to examine the link between brand trust and brand orientation as independent variables and performance of the company as a dependent variable with intervening role of brand equity and the moderating role of innovation in the context of small and medium sized enterprises in Malaysia. The present study addresses the above argument with an effort to increase the understanding of healthcare branding context among SME in Malaysia. With regard to the literature, this study makes two important contributions:

(1) To new marketing knowledge on the area of healthcare branding in SMEs. This research demonstrates how ideas about branding are translated and communicated from the perspective of SME healthcare owners.

(2) To identification of the branding dimensions that contribute to the financial and marketing performance of small and medium sized enterprises (more specifically, healthcare centers). To date, this research will be a pioneering study in Malaysia in measuring the healthcare branding and performance in SME.

\section{Literature Review}

\subsection{Hypotheses Development}

To further understand the theories related to the framework, we can use major theories such as theory of Resource-Based View (RBV) and Diffusion of Innovation (process innovation) to explain the construct validity of SME Branding for this research. The resource-based view argues that firms possess resources that help to gain competitive advantage, which leads to a superior long-term performance [10,35]. Many researchers have argued that differences may occur in many forms of resources such as innovations and patents [19]. However, Klein [41] stated that such differences may also formed by subjective judgments that imagined by entrepreneurs. In various marketing fields, RBV is mainly used to compel the structure it suggests in the integration of diverse resources in a way to make clear the differential, synergistic effects on performance and the contingencies that are interrelated [27]. The same is applied to this study's framework that involves multiple dimensions structure such as branding effects on the organization performance [29, 30]. Three main variables such as brand trust, brand orientation, and brand equity selected for this study were found effective 
resources in building brands internally. On the other hand, RBV in marketing strategy indicates that performance is measured considering several indicators, e.g., market share [34], profitability [68], and return on investments [51]. To the other side, Medical and technological innovation adoption in healthcare differs when made by owners or individuals. Once an owner decides to use a device or piece of technology, he or she must consider the impact not only on the patient and the practice, but also on the performance of the company. The value created from the innovation adoption must be evaluated. An example of a great diffusion of innovation is the adoption of X-ray. Seelor and Mair [63] proposed a framework of adopting innovations which entered an organization through diffusion process in order to guide evaluation of factors influencing organization capacity in continuous innovation for social sector organizations such as the healthcare centers. In short, the diffusion of innovations theory is a useful systemic framework to describe how well small and medium sized enterprises implement and capture innovation culture in the strategic management. If SMEs contribute to productivity in developing market offerings, their competencies can result in an economic dynamism. These offerings can lead to durable and beneficial market positions, which can bring about greater financial performance for SMEs.

\subsubsection{Linking Brand Equity and Brand Trust}

To achieve customer loyalty in the context of brand building, one of the most important components, which needs to be taken well into account, is the concept of trust $[7,17,25]$. There are two-dimensional ideas of trust, which are commonly found in the management and marketing literature [23, 24, 28, 54]. On the other side, brand equity also creates value for both the customer and the company [8]. In addition, its incremental utility and value is endowed to a product or service by the brand name [40, 49, 69, 71]. Attributes such as provocativeness, risk-taking and innovation portray an entrepreneurial mindset [20,43]; they are able to identify the opportunities in market and exploit them through combination or recombination of the resources obtainable by the owner's venture [21, 37, 65].Moreover, according to Mohamed and Daud [55], no study has examined the firms' values such as brand trust and brand equity in one particular construct. Therefore, there is a significant gap that should be filled in order to gain knowledge about trust and equity relationship.

\section{H1: Brand trust affects brand equity in SME}

\subsubsection{Linking Brand Orientation Affects Brand Equity}

Literature characterize brand orientation by brand dominance of incorporate strategic thinking and a relatively consistent, constant, consumer-relevant branding strategy that can be plainly distinguished from competition [11,33]. Mzungu et al., [48] conducted research to measure the first stage of safeguarding the brand equity. That is to adopt brand orientation. It is one of the significant 
ingredients to manage the brand strategically for all types of companies even SMEs. Within the first stage, there are three key propositions adopted for building brand orientation. First, creating a brand orientation mind set which helps the organization to create a sustainable competitive advantage for the brand. The second step involves clearly defining the brand in terms of its purpose, vision, values, competencies, and aspirations. The last step of building brand orientation mind set is communicating the brand because defining the brand without communicating it within the organization will open to multiple interpretations at its various touch points. The literature has shown that brand orientation has a powerful impact on brand equity $[12,48,61]$ and also influences the performance of a company $[11,32]$. Brand orientation is suitable to be tested as part of this research because of its robust and dynamic interaction with brand management and it is rarely being examined within healthcare industry specifically. Thus, the following hypothesis is needed to be proposed.

\section{H2: Brand orientation affects brand equity in SME}

\subsubsection{Link between Brand Equity and SME Performance}

Brand equity has been a link between customer and firm in the past [64]. However, to numerous managers and researchers, it has been attractive to measure the return of intangible assets, e.g., brand equity [64] to the company. Realizing the immense standing of brand equity in a firm performance, there is a need to execute brand equity to increase the value of a company. Berthon et al. [14] strongly agree that owners or managers are required to monitor brand equity. In a healthcare point of view, it is important to employ available healthcare marketing resources and programs in an improved way in order to gain a greater influence within the community. Understanding brand equity is a critical starting point for planning marketing strategy and tracking progress toward goals [31]. The brand management research is primarily aimed at exploring the actual value of these intangible assets and applying that information concretely to the improvement of the firm's standing and perception. Thus, the third and fourth hypotheses are in two aspects:

\section{H3a: Brand equity affects SME financial performance}

\section{H3b: Brand equity affects SME marketing performance}

\subsubsection{Brand Equity Mediates the Relationship between Brand Trust, Brand Orientation, and SME Performance}

In a study conducted by Yoo et al. [69], the framework was conceptualized based on the extension of [2]model. Three main propositions on brand equity were derived. First, brand equity creates value for both the customer and the firm. Second, the value for the customer enhances value for the firm, and finally, brand equity consists of multiple dimensions. Yoo et al. [69] extended the model by placing into a separate construct, brand equity dimensions, and value for the 
customer and the firm. Brand equity acted as a mediator between brand assets and its consequences. The theory proves that brand equity can be created, maintained, and expanded by strengthening its dimensions. Yoo et al. [69] emphasized on brand equity linkages and noted a very imperative future research issue, namely the interaction effects and consequences of brand equity. Although there are some studies suggesting that brand equity acts as intermediate variable [4, 64], none has measured branding in such an approach amongst small and medium sized healthcare centers. It provides directions for owners of healthcare centers in terms of creating and enhancing brand trust and brand orientation through brand equity in a way to lead to sustainable marketing and financial performance. This has resulted in the fourth hypothesis as follows.

H4a: Brand equity mediates the relationship between brand trust and financial performance

H4b: Brand equity mediates the relationship between brand trust and marketing performance

H4c: Brand equity mediates the relationship between brand orientation and financial performance

H4d: Brand equity mediates the relationship between brand trust and marketing performance

\subsubsection{Innovation Moderates the Relationship between Brand Equity and SME Performance}

Literature consists of numerous studies carried out on performance of SMEs plus their financial and marketing issues and their drivers [50, 56, 59] because it is significant to evaluate in a different manner in a way to be adapted with customer's constantly evolving needs and preferences [36, 46, 66]. The main contribution of the study conducted by Merrilees et al., [52] to the social sciences is the evaluation of auxiliary SME capabilities as determinants of marketing performance. The notion explaining the marketing performance lies in two main marketing variables: branding and innovation. In our study, innovation is included in the framework to moderate the relationship between branding and SME performance (marketing and financial). Moreover, findings of $\mathrm{Li}$ et al. [45] showed that innovation moderated the relationship between market orientation and performance. In addition, innovation for this study's framework has been built further as a moderator by relating it to the business performance in the presence of a branding plan. Only one study has been conducted so far adopting this approach [52] but it was constructed in a developed country raising a query if the model works for an emerging market. Accordingly, the conceptual framework in this study was modified to examine how the relative contribution of mechanism works in a developing market. Therefore, the fifth hypothesis was constructed as follow, 
H5a: Innovation moderates the relationship between brand equity and financial performance

H5b: Innovation moderates the relationship between brand equity and marketing performance

\subsection{Development of the Brand Dimension Model}

The conceptual framework is extended in two ways. First, we are setting brand equity in a joint construct illustrated in Figure 1: brand equity with its dimensions of brand trust and brand orientation and the influence of brand equity on the performance of the healthcare center. Secondly, innovation has positive impact on SME performance in several studies (e.g. [44] and [60]) and supported by theory of diffusion of innovation.

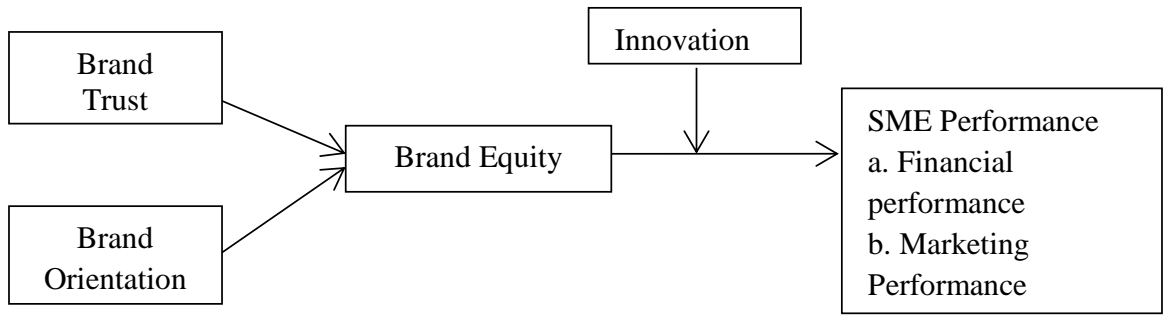

Figure 1

Conceptual Framework of SME Branding Dimension

\section{Research Method}

\subsection{Variables and Measurement}

This study requires measurement of brand trust, brand orientation, brand equity, and SME performance. We made use of a Likert scale to score all measures; the options were ranged between 1 ('do not agree at all') and 5 ('strongly agree'). In this scale, higher scores showed a higher level of the construct in question. Pilot testing for both qualitative and quantitative data was done in order to avoid vagueness or confusing questions. Validity of qualitative and quantitative data was examined through the reflective measurement model assessment. The key criteria for this study were indicator reliability, composite reliability, and convergent validity. Furthermore, discriminant validity was achieved. Every reflective construct had to share more variance with its own indicators compared to other constructs in the path model [26]. The constructs were deemed appropriate for PLS-SEM analyses in case all these requirements criteria were met. 


\subsection{Sampling}

The samples from this study are collected from healthcare services provided in Johor Bahru, Malaysia, mainly from the developed area around Iskandar Malaysia Township or Nusajaya. Johor Bahru is strategically located near many other medical hubs such as Singapore and Indonesia. The health care development in Iskandar, Malaysia aims to capture patients who are from around these regions and seeking quality and cost-effective healthcare services. It is aimed at becoming the next medical destination. Therefore, Iskandar Malaysia in Johor Bahruis known as a billion-dollar industry projected to grow. It is the economic potential that has led the Malaysian government to consider the healthcare sector as one of the country's 12 National Key Economic Areas (ETP Annual Report, 2014).

The sampling procedure for both qualitative and quantitative parts was done using non-probability sampling. The reasons for choosing non-probability sampling were (i) first, this research cannot meet the criteria of probability sampling; most of the experts, doctors, and pharmacist in the health industry decline to cooperate. (ii) Second, the procedure of selecting respondents to be included in the sample is much easier, quicker, and cheaper.

\subsubsection{Qualitative Sampling}

For qualitative part of the study, a snow ball sampling procedure was done. As respondents from health industry are hard to reach, the potential subjects were selected based on recommendation and identification by the initial subject who also meets the criteria of the research. In this study, one of the branding experts from SME Corporation was chosen followed by the Chairman of Malaysia Medical Association. The determination of sample size follows Becker, Bryman et al. [13] theory where the observation stops when no new theoretical insights are being gleaned from the data.

\subsubsection{Quantitative Sampling}

The sampling of the SME entrepreneurs, owners, or managers was initialized using probability sampling based on the lists provided by Syarikat-Syarikat Suruhanjaya Malaysia (SSM) and followed by a quota sampling method that is a non-probability sampling method. There are four town councils administered by the local authorities in Johor Bahru, the largest population in Johor state, as explained in Figure 2. About 400 questionnaires were distributed to potential respondents of the four main Johor Bahru regions namely: City council of Johor Bahru, City council of Central Johor Bahru, City council of Pasir Gudang and Nusajaya. Initially, 200 questionnaires were distributed in the first phase to all health care-related providers from clinics, pharmacies, dental clinics, and maternity centers in Johor Bahru. A total of 57 completed questionnaires were received. Of that number, the study then extended again to gather even more 
respondents. In the second phase, 200 questionnaires were distributed, and we could manage to gather 67 completed questionnaires (Figure 2).

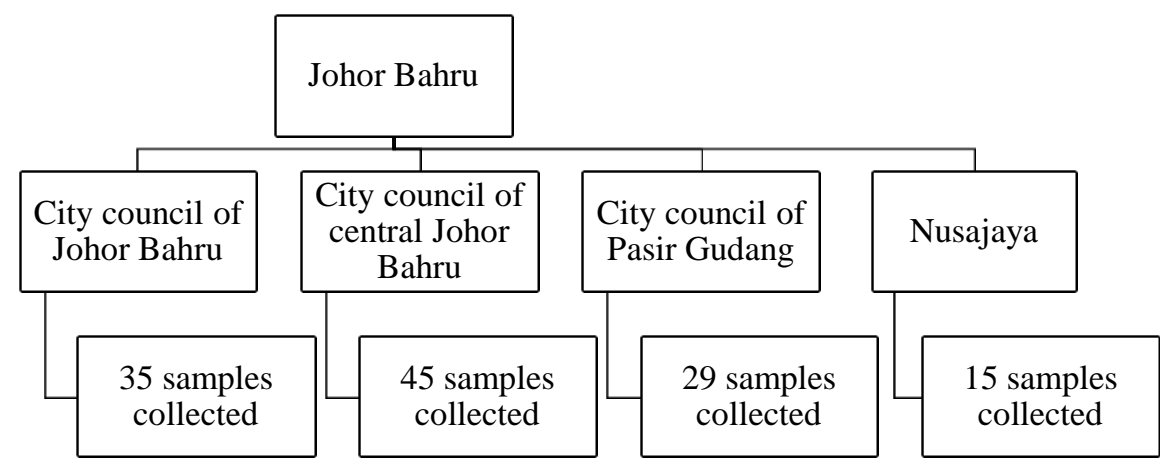

Figure 2

Cluster - Systematic (Proportions) Sampling Area Distribution and Total Samples Collected

\section{Data Analysis}

In-depth interviews were conducted as the preliminary stage for qualitative research followed by a distribution of survey questionnaires as the quantitative part of the study. All collected qualitative data were tabulated, coded, retrieved, summarized, drawn, and verified. To calculate, Burn and Bush [16] formula was adopted, assuming that there was a great expected variability $(50 \%)$ and for \pm 10 percent accuracy at the 95 percent level of confidence, and sufficient sample size for data collection was at least 96. Descriptive analysis was done to describe the basic features of the data in the study. Bootstrapping, blindfolding, CTA-PLS, analysis of moderating effect, and multi-group analysis were tested and analyzed. Consequently, a comprehensive evaluation was verified using reflective and formative measurement. Finally, PLS-SEM analyses for moderating and mediating and importance-performance analyses were described as closing.

\section{Results}

Five interviewees were selected from different nature of businesses such as SMEs, Health center and pharmacy. The respondents were selected carefully by taking into account their experience in the industry. The main focus of the interview was mainly to answer the aspects of branding dimension and the performance of a company. 


\subsection{Analysis of Qualitative Data}

The analysis of all branding dimensions were analyzed in the interview and divided into categories: general branding categories, brand trust, brand orientation, brand equity, innovation financial and marketing performance. The first part of the interview on general branding inquiries showed that most of the respondents realized the importance of branding for company performance. Trust is evaluated among the healthcare owners based on few indications of a good brand trust; reliability, credibility, competitive advantage, partnering with reputable associates, customer recognition, values and keeping promises. Brand dimension was claimed to be understood by most of the respondents. Nevertheless, when probed further, only two out of the five respondents were able to describe the mechanism of brand dimension. Three out of five participants were clear about the identity of the health care centers. Most of the owners were still unclear of their organization image. Even though four out of five respondents stated that they recognized brand as a valuable asset and strategic resource for development; only a few actually understood the brand values. Three respondents, which included managers and owners, stated that the development of brand in the health care center is the responsibility of every employee and there is in fact a good communication in regard to branding within the organization. However, throughout the interviews, only one owner stated that the health care center uses all marketing activities to develop a brand. Surprisingly, none of the respondents specified that an active and effective management is essential for achieving competitive advantage. From the insights gained from the interview regarding brand trust, four out of five respondents indicated that reliability, competitive advantage, and credibility were important for brand trust. Furthermore, innovation is fundamental for health care providers. Four out of five respondents stated that new ideas and new services must be constantly introduced to the company to keep updated with the competitors. Lastly, the health center performance is based on two factors: financial performance and marketing performance. All of the interviewees believed that financial performance is measured by how profitable the business is. Moreover, the return of investment and how well the company reaches financial goals are also two main measurements used to quantify the financial performance.

\subsection{Analysis of Quantitative Data}

This section describes the results of descriptive analysis of demographic variable. The data showed that most of the respondents were male $(75.8 \%)$, while female owners were only $24.2 \%$ of the total respondents. Most of the respondents were Chinese with a total of 49.2 percent and the rest of them were Indian $(30.6 \%)$ and Malay (20.2\%). Most of the small and medium sized enterprises were run by the owners $(80.6 \%)$ themselves and only few were supervised by a manager $(19.4 \%)$. Most of the owners of the small and medium sized enterprises were not given 
financial assistance for brand building activities. Only 12.9 percent was funded before the business started.

According to the demographic data, $41.1 \%$ of the health centers claimed that branding needs to be considered before setting up the organization. Almost half of the respondents thought that branding is a strategic point of view for company management in which the rewards of having a strong brand is become advantage to them. Most of the companies have an annual average growth between 0 to $20 \%$. Despite having no financial assistance, these health centers were able to grow in business performance annually. Surprisingly, about $26.6 \%$ of the health centers have experienced no growth.

\subsection{Measurement Model}

The reflective measurement model was evaluated in terms of both validity and reliability. For each construct in this research, the reflective scale items were considered to be sufficient and appropriate to represent the construct domain. The overall measurement model and the indicator loadings of the final set of items were used for independent and dependent measurements. From the measures, eight indicators showed factor loading below 0.7. In case of the six reflectivelymeasured constructs, the composite reliabilities were ranged between 0.913 and 0.924 , which is much greater than the minimum requirement of 0.70 . Each latent variable AVE (Average Variance Extracted) was checked regarding the convergent validity. All AVE values were shown greater than the threshold of 0.5, hence indicating convergent validity for all constructs. As obviously shown by the criterion, in case of the reflective constructs, all AVE values were greater than the squared inter construct correlation indicating that the discriminant validity was well established.

\subsection{Structural Model}

A highly recommended approach is PLS-SEM path weighting since it is capable of providing the greatest $\mathrm{R}^{2}$ value for endogenous latent variables and also it can be generally applied to all estimations and specifications of the PLS path model. However, before interpreting the path coefficients, a test was conducted on the structural model regarding its collinearity. It was of a high importance since the path coefficients estimation was on the basis of the ordinary least squares regressions [53]. VIF values of the analyses found were in ranged between 1.062 and 1.568; this ensured that the structural model results were not negatively affected by collinearity. The calculation process of the PLS results was iterated for 300 times, which is large enough for data analysis [26]. When checking the PLSSEM result, the algorithm needs to be checked to be terminated because of the stop criterion. This value should be sufficiently small, i.e., $10^{\wedge}-5$. In the structural model analysis, the last step is about the relevance and significance of the 
structural model relationships. As demonstrated by the results obtained from the bootstrapping procedure, seven out of eight structural relationships were proved significant at $(p \leq 0.05)$, see Figure 3 . The inner model suggested that brand orientation had the strongest effect on brand equity with path coefficient of 0.679 in this research. Statistics showed that there was a significant relationship between brand equity and brand orientation. Surprisingly, the path coefficient between brand trust and brand equity is not significant at only 0.075 . This is because the standardized path coefficient is lower than 0.1 . The hypothesized path relationship between brand trust with financial performance (0.251) and marketing performance (0.239) were rather weak but significant. To conclude, brand orientation is a strong predictor for brand equity, while brand trust is a weak predictor for brand equity. The results showed that all relationships are significant with $t$ value $\geq 1.96$ except for one relationship where brand trust does not affect brand equity. At $90 \%$ level of confidence, $t$ value is 1.066 (see Table 1).

Table 1

Path Significance in Bootstrapping

\begin{tabular}{|c|c|c|c|c|c|c|}
\hline $\begin{array}{c}\text { Hypothes } \\
\text { is }\end{array}$ & Paths & $\begin{array}{c}\text { Path } \\
\text { Co. }\end{array}$ & SD & $\begin{array}{c}\text { T } \\
\text { Statistics }\end{array}$ & $\begin{array}{c}\text { P } \\
\text { Values }\end{array}$ & Result \\
\hline H1 & $\begin{array}{c}\text { Brand Trust -> } \\
\text { Brand Equity }\end{array}$ & 0.075 & 0.071 & $1.066^{* * *}$ & 0.293 & rejected \\
\hline H2 & $\begin{array}{c}\text { Brand Orientation } \\
->\text { Brand Equity }\end{array}$ & 0.579 & 0.062 & $9.413^{* *}$ & 0.000 & Accepted \\
\hline H3a & $\begin{array}{c}\text { Brand Equity -> } \\
\text { Financial } \\
\text { Performance }\end{array}$ & 0.545 & 0.094 & $5.800^{* *}$ & 0.000 & Accepted \\
\hline H3b & $\begin{array}{c}\text { Brand Equity -> } \\
\text { Marketing } \\
\text { Performance }\end{array}$ & 0.679 & 0.075 & $9.001^{* *}$ & 0.000 & Accepted \\
\hline
\end{tabular}

\subsection{Mediation Analysis}

After determination of the valid path coefficients, mediation analysis was examined. The analysis was based on the study of Hair et al. [26] where three main ideas listed by F. Hair Jr, Sarstedt, Hopkins and G. Kuppelwieser [26] were fulfilled. To satisfy the mediation effect rules of thumb, brand trust must have a relationship with brand equity. Looking at Table 1, we can see that the path coefficient of brand trust and brand equity is not significant. Therefore, brand equity does not mediate the relationship between brand trust with financial and marketing performance. In the final step, the strength of mediation was tested using variance accounted for (VAF). This final analysis step resulted in VAF values that were smaller than 1 as stated in Table 2). Based on findings of Hair et al. [63], this value indicates that the relationship is mediated. 


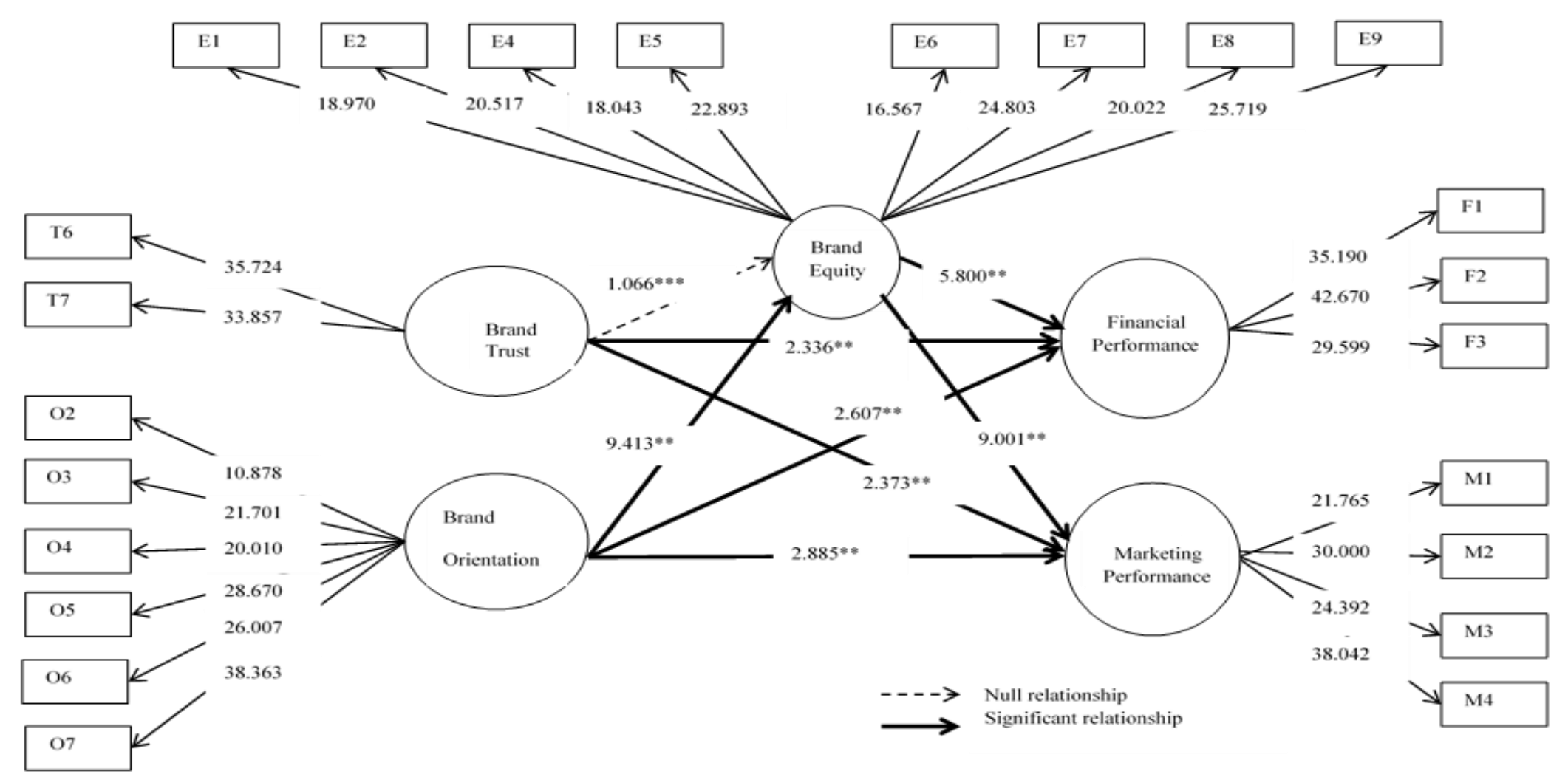

Figure 3

Bootstrap result 


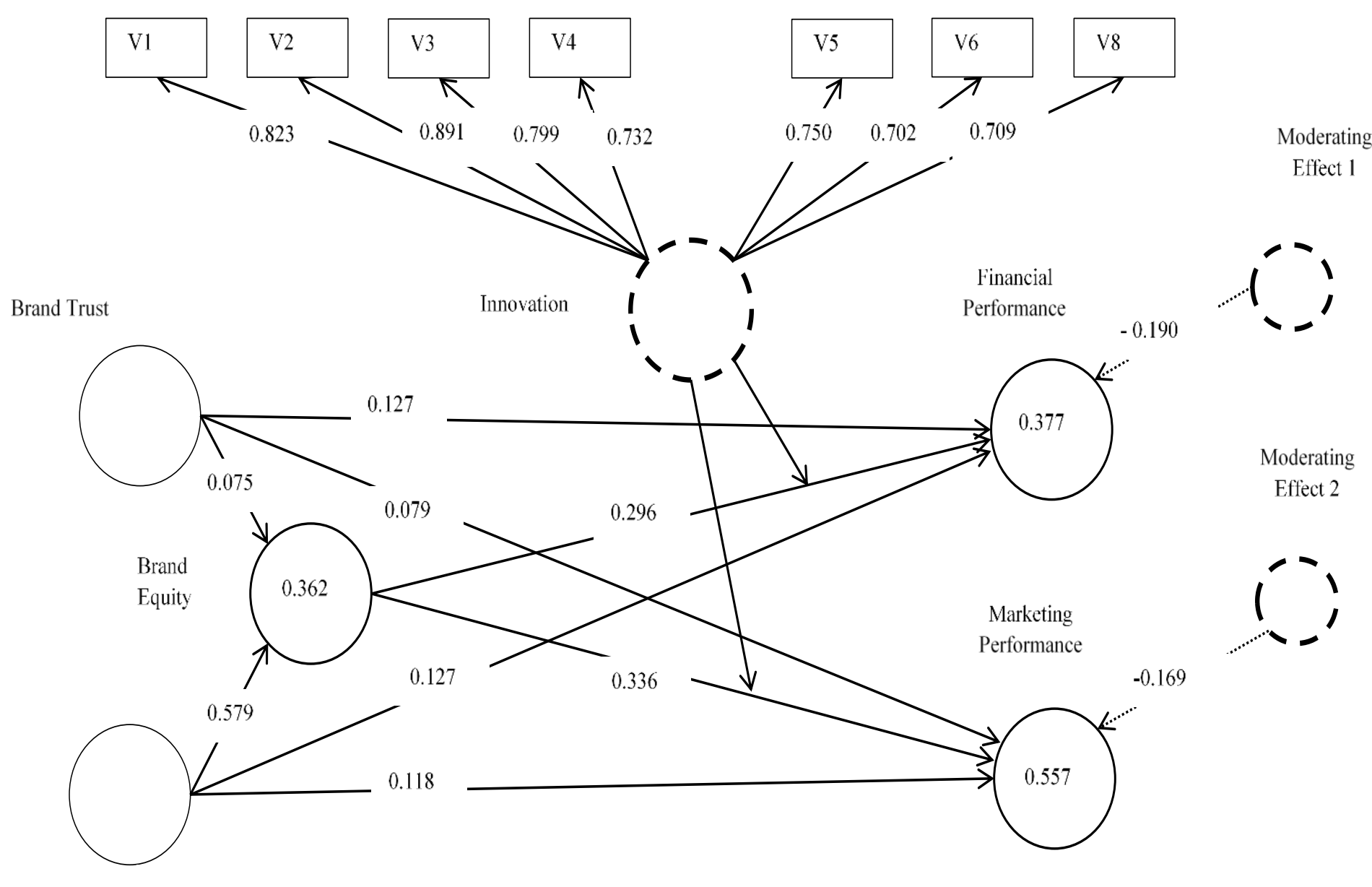

Brand Orientation

Figure 4

Moderator Model in SMART PLS 
Brand orientation and marketing performance indicated the highest VAF value of 0.610 , which showed that about $61.0 \%$ of the total effect of brand orientation on marketing performance was explained by indirect effect. Brand orientation and financial performance achieved a VAF value of 0.569 . Thus, the two relationships were mediated by brand equity (see Table 2). These relationships showed a partial mediation effect. According to Hair et al., (2014), a situation in which the VAF is larger than $20 \%$ and less than $80 \%$ can be characterized as partial mediation. Anything higher than $80 \%$ is considered full mediation.

Table 2

Mediation Value of Direct Effect, Indirect Effect, Total Effect and Variance Accounted For (VAF)

\begin{tabular}{|l|c|c|c|c|}
\hline & $\begin{array}{c}\text { Direct } \\
\text { effect } \\
(\boldsymbol{c})\end{array}$ & $\begin{array}{c}\text { Indirect } \\
\text { effect } \\
(\boldsymbol{a x b})\end{array}$ & $\begin{array}{c}\text { Total } \\
\text { effect } \\
(\boldsymbol{c}) \\
+ \\
(\boldsymbol{a x b})\end{array}$ & VAF \\
\hline $\begin{array}{l}\text { brand orientation } \rightarrow \text { brand equity }(a) \\
\text { brand equity } \rightarrow \text { marketing performance }(b) \\
\text { brand orientation } \rightarrow \text { marketing performance }(c)\end{array}$ & 0.251 & 0.393 & 0.644 & 0.610 \\
\hline $\begin{array}{l}\text { brand orientation } \rightarrow \text { brand equity }(a) \\
\text { brand equity } \rightarrow \text { financial performance }(b) \\
\text { brand orientation } \rightarrow \text { financial performance }(c)\end{array}$ & 0.239 & 0.316 & 0.555 & 0.569 \\
\hline
\end{tabular}

\subsection{Moderation Analysis}

To conduct the significance test, bootstrapping procedure with 500 bootstrap samples using no sign changes option was used. The analysis yields a $t$ value of 0.717 for path linking the interaction term and financial performance. Similarly, for marketing performance in Figure 4, interaction effect was at $t$ value $=0.794$. According to Hair et al., (2014), there is no significant moderating effect of innovation on the relationship between brand equity and financial performance and marketing performance where the analysis yields less than $t=1.96$ (see Table $3)$.

Table 3

Summary of moderating effect

\begin{tabular}{|l|c|c|c|}
\hline & $\begin{array}{c}\text { Predictive Value } \\
\boldsymbol{R}^{\mathbf{2}}\end{array}$ & $\begin{array}{c}\text { Effect Size } \\
\boldsymbol{f}^{\mathbf{2}}\end{array}$ & Relationship \\
\hline $\begin{array}{l}\text { Moderating Effect 1 } \\
\text { (Financial Performance) }\end{array}$ & 0.023 & 0.001 & Non-significant \\
\hline $\begin{array}{l}\text { Moderating Effect 2 } \\
\text { (Marketing Performance) }\end{array}$ & 0.010 & 0.000 & Non-significant \\
\hline
\end{tabular}




\section{Discussions}

Multiple studies have shown that brand trust affects brand equity [22, 55]. However, the results of this study showed no significant relationship between brand trust and brand equity as shown in figure 4 . Ultimate justification can be the fact that trust is not evaluated by one person alone because trust comes to exist at the highest level between the consumer and the brand consumed, where the emotional investment is made between the two parties. A health center does not typically move forward to the identity or consistency level in establishing a trusted relationship with a certain brand until the brand effectively proves its capability of living up to expectations. Respondents to the qualitative part of the research reflected the importance of brand orientation in the health care business. According to literature, recognizing brand as a valuable asset and strategic resource has to be continuously developed and protected in the best possible way [32]. The outcomes were also consistent with Gromark and Melin [32] findings where indicating that with a proper brand orientation, a company will benefit in terms of profits. Therefore, the development of healthcare brand is not the responsibility of only a small group within the company, but everyone in the company is responsible [12,32].

Results showed that brand equity was not a mediator between brand trust and any one the marketing or financial performance; thus, hypotheses $4 \mathrm{a}$ and $4 \mathrm{~b}$ were rejected. The reason behind this is that findings showed no significant relationship between brand trust and brand equity opposing to Ballester and Aleman [22] study indicating the significance of brand trust in the development of brand equity. As mentioned earlier, brand trust cannot determine brand equity of a health care center because the trust relationship is between a health care provider and the customer rather than the firm equity with the customer.

From the moderating analysis, innovation is not a moderator for brand equity and SME performance, therefore, hypothesis $\mathrm{H} 5 \mathrm{a}$ and $\mathrm{H} 5 \mathrm{~b}$ were rejected. It is surprisingly different from the literature arguing innovation influences brand equity, hence affecting the performance of a company $[18,45]$. The main cause behind this might be the degree of innovation in the respective health center. According to one study conducted by Zhang et al. [70], the degree of innovation has a positive effect on both brand equity and value equity, which eventually impacts a company's performance. Thus, the reason a health care center launch innovative products or services must be not only boosting the sales through enhancing the customer value. Additionally, it also improves the brand image, which affects the organization performance.

The SME business success measurement using financial and marketing performance was supported by Hooley et al. [34]; Vorhies and Morgan [68]; Merrilees et al. [52]. All items loadings were found to be above 0.8; therefore, items were reliable for interpretation. The results of marketing and financial performance, similar to performance measurement and evaluation systems, are 
important to both owners and managers. Moreover, brand equity was found to have relationship with financial performance. Hypothesis $3 \mathrm{a}$ was accepted and also supported by past studies where financial performance was reported to be greatly affected by brand equity [3, 18, 67, 69]. The wisdom of brand equity concept even for services industry like health care is found to prevail. The results imply that the health care providers need to build and safeguard brand equity to have a better performance. They must design appropriate marketing activities to have their brand internally and externally known by customers and employees, hence increasing the sales revenue.

Supported by Merrilees et al., (2011), the performance measurement falls into two categories: financial and marketing performance. These two measurements have shown different significance level toward brand equity. According to findings, brand equity showed a higher significant value to marketing performance compared to financial performance. Hypothesis $3 \mathrm{~b}$ was accepted; it follows Keller [38] definition where brand equity is defined in terms of the marketing effects uniquely attributable to the brand.

\section{Conclusion}

This research has highlighted the need for a greater appreciation of the importance and relevance of brand orientation, brand equity, and RBV and how they can affect the business performance of small firms. In addition, the model was tested using an advance technique via partial least square of structural equation modeling (SEM) and resulted in a strong empirical support. It is proposed that the new SME branding dimension is appropriate to conceptualize the SME branding situation in Johor Bahru, Malaysia. The small sample size was the main issue for this study. This research was limited to a number of private health care centers selected from the four-main district of Johor Bahru and responses were collected from one owner of each center. The limitation of questionnaire was found where there was no way of checking misinterpretations and unintelligible replies by the respondents. Generally, this study had low response rates, due to uncooperative respondents. Future research should focus on implementing that the current model be tested in different regions or countries and different economic status to measure the branding efforts, and the influences in the business performance. The economic effects may portray differently especially for each group, respectively region in North America, Europe and Asia. Moreover, future studies could focus on empirically examining the framework with a large sample size.

\section{References}

[1] Aaker, D. A. and Jacobson, R.: The value relevance of brand attitude in high-technology markets, Journal of marketing research, 38 (2001) No. 4, pp. $485-493$

[2] Aaker, D. A.: Managing Brand Equity, New York, Maxweel MacmillanCanada, Inc, (1991) 
[3] Aaker, D. A.: Managing brand equity, simon and schuster, (1991)

[4] Aaker, D.: Innovation: Brand it or lose it, California Management Review, 50 (2007) No. 1, pp. 8-24

[5] Aaker, D.: Innovation: Brand it or lose it. California Management Review, 50 (2007) No. 1, pp. 8-24

[6] Abimbola, T. and Kocak, A.: Brand, organization identity and reputation: SMEs as expressive organizations: A resources-based perspective, Qualitative Market Research: An International Journal, 10 (2007) No. 4, pp. 416-430

[7] Ahmad, F. S. and Baharun, R.: A crucial role of entrepreneur in B2B branding: A case from Malaysia, Faculty of Management and Human Resource Development (2010)

[8] Akbar, M. M. and Parvez, N.: Impact of service quality, trust, and customer satisfaction on customers loyalty, ABAC Journal, 29 (2009)

[9] Baldauf, A., Cravens, K. S. and Binder, G.: Performance consequences of brand equity management: evidence from organizations in the value chain, Journal of product \& brand management, 12 (2003) No. 4, pp. 220-236

[10] Barbis, D.: Brand model creation for a small healthcare service, (2012)

[11] Barney, J.: Firm resources and sustained competitive advantage, Journal of management, 17 (1991) No. 1, pp. 99-120

[12] Baumgarth, C. and Schmidt, M.: How strong is the business-to-business brand in the workforce? An empirically-tested model of internal brand equity'in a business-to-business setting, Industrial Marketing Management, 39 (2010) No. 8, pp. 1250-1260

[13] Baumgarth, C.: Brand orientation of museums: Model and empirical results, International Journal of Arts Management (2009) pp. 30-45

[14] Becker, S., Bryman, A. and Ferguson, H.: Understanding research for social policy and social work: themes, methods and approaches, Policy Press (2012)

[15] Berthon, P., Ewing, M. T. and Napoli, J.: Brand management in small to medium- sized enterprises, Journal of Small Business Management, 46 (2008) No. 2, pp. 27-45

[16] Berthon, P., Hulbert, J. M. and Pitt, L. F.: Brand management prognostications, MIT Sloan Management Review, 40 (1999) No. 2, p. 5

[17] Burns, A. C. and Bush, R. F.: Prentice Hall, Upper Saddle River, New Jersey (2003)

[18] Chaudhuri, A. and Holbrook, M. B.: The chain of effects from brand trust and brand affect to brand performance: the role of brand loyalty, Journal of marketing, 65 (2001) No. 2, pp. 81-93 
[19] Cheng, C. C. and Krumwiede, D.: The effects of market orientation and service innovation on service industry performance: An empirical study, Operations Management Research, 3 (2010) No. 3-4, pp. 161-171

[20] Chuang, L.-M. and Chao, S.-T.: A Cross-National Comparison of Entrepreneurial Opportunity Recognition: Application of a Self-Organizing Map with a Resource-Based view, INTERNATIONAL RESEARCH JOURNAL OF FINANCE AND ECONOMICS (2013) No. 108, p. 8

[21] Covin, J. G. and Slevin, D. P.: Strategic management of small firms in hostile and benign environments, Strategic management journal, 10 (1989) No. 1, pp. 75-87

[22] Davidsson, P., Delmar, F. and Wiklund, J.:Entrepreneurship as growth: Growth as entrepreneurship, In Entrepreneurship and the Growth of Firms, Edward Elgar Publishing, 2006 , pp. 21-38

[23] Delgado-Ballester, E. and Luis Munuera-Alemán, J.: Does brand trust matter to brand equity?, Journal of product \& brand management, 14 (2005) No. 3, pp. 187-196

[24] Delgado-Ballester, E., Munuera-Aleman, J. L. and Yague-Guillen, M. J.: Development and validation of a brand trust scale, International Journal of Market Research, 45 (2003) No. 1, pp. 35-56

[25] Doney, P. M. and Cannon, J. P.: An examination of the nature of trust in buyer-seller relationships, the Journal of Marketing (1997) pp. 35-51

[26] Eggers, F., O’Dwyer, M., Kraus, S., Vallaster, C. and Güldenberg, S.: The impact of brand authenticity on brand trust and SME growth: A CEO perspective, Journal of World Business, 48 (2013) No. 3, pp. 340-348

[27] F. Hair Jr, J., Sarstedt, M., Hopkins, L. and G. Kuppelwieser, V. Partial least squares structural equation modeling (PLS-SEM) An emerging tool in business research, European Business Review, 26 (2014) No. 2, pp. 106121

[28] Fang, E., Palmatier, R. W. and Grewal, R.: Effects of customer and innovation asset configuration strategies on firm performance, Journal of Marketing Research, 48 (2011) No. 3, pp. 587-602

[29] Ganesan, S.: Determinants of long-term orientation in buyer-seller relationships, the Journal of Marketing (1994) pp. 1-19

[30] Gavurová, B., Kováč, V. and Fedačko, J.: Regional disparities in medical equipment distribution in the Slovak Republic-a platform for a health policy regulatory mechanism. Health economics review, 7 (2017) No. 1, p. 39

[31] Gavurová, B., Kováč, V. and Šoltés, M.: Medical Equipment and Economic Determinants of Its Structure and Regulation in the Slovak Republic,in Encyclopedia of Information Science and Technology, Fourth Edition, (2018) pp. 5841-5852 
[32] Gombeski Jr, W. R., Martin, B. and Britt, J.: Marketing-Stimulated Wordof-Mouth: A Channel for Growing Demand, Health marketing quarterly, 32 (2015) No. 3, pp. 289-296

[33] Gromark, J. and Melin, F.: The underlying dimensions of brand orientation and its impact on financial performance, Journal of Brand Management, 18 (2011) No. 6, pp. 394-410

[34] Hankinson, G.: Location branding: A study of the branding practices of 12 English cities, Journal of Brand Management, 9 (2001) No. 2, pp. 127-142

[35] Hooley, G. J., Greenley, G. E., Cadogan, J. W. and Fahy, J.: The performance impact of marketing resources, Journal of business research, 58 (2005) No. 1, pp. 18-27

[36] Hoopes, D. G., Madsen, T. L. and Walker, G.: Guest editors' introduction to the special issue: why is there a resource- based view? Toward a theory of competitive heterogeneity, Strategic Management Journal, 24

[37] Hult, G. T. M., Hurley, R. F. and Knight, G. A.: Innovativeness: Its antecedents and impact on business performance. Industrial marketing management, 33 (2004) No. 5, pp. 429-438

[38] Ireland, R. D., Hitt, M. A., Camp, S. M. and Sexton, D. L.: Integrating entrepreneurship and strategic management actions to create firm wealth, Academy of Management Perspectives, 15 (2001) No. 1, pp. 49-63

[39] Keller, K. L.: Brand synthesis: The multidimensionality of brand knowledge, Journal of consumer research, 29 (2003) No. 4, pp. 595-600

[40] Keller, K. L.: Conceptualizing, measuring, and managing customer-based brand equity, the Journal of Marketing (1993) pp. 1-22

[41] Keller, K. L.: Strategic brand management, Upper Saddle River, NJ, Prentice Hall, 1998

[42] Klein, P. G.: Opportunity discovery, entrepreneurial action, and economic organization, Strategic Entrepreneurship Journal, 2 (2008) No. 3, pp. 175190

[43] Krake, F. B.: Successful brand management in SMEs: a new theory and practical hints, Journal of Product \& Brand Management, 14 (2005) No. 4, pp. 228-238

[44] Kraus, S.: The role of entrepreneurial orientation in service firms: empirical evidence from Austria, The Service Industries Journal 33 (2013) pp. 427 444

[45] Laforet, S.: In Organizational Culture, Business-to-Business Relationships, and Interfirm Networks, Emerald Group Publishing Limited (2010) pp. 341-362

[46] Li, Y., Zhao, Y., Tan, J. and Liu, Y.: Moderating effects of entrepreneurial orientation on market orientation- performance linkage: Evidence from 
Chinese small firms, Journal of small business management, 46 (2008) No. 1, pp. 113-133

[47] Lin, C.-H., Peng, C.-H. and Kao, D. T.: The innovativeness effect of market orientation and learning orientation on business performance, International journal of manpower, 29 (2008) No. 8, pp. 752-772

[48] Low, G. S. and Fullerton, R. A.: Brands, brand management, and the brand manager system: A critical-historical evaluation, Journal of marketing research (1994) pp. 173-190

[49] Marinova, S., Cui, J., Marinov, M. and Shiu, E.: Customers relationship and brand equity: A study of bank retailing in China, WBC, poznau, 9 (2011) pp. 6-9

[50] Mavondo, F. and Farrell, M.: Cultural orientation: its relationship with market orientation, innovation and organisational performance, Management Decision, 41 (2003) No. 3, pp. 241-249

[51] Menguc, B. and Auh, S.: Creating a firm-level dynamic capability through capitalizing on market orientation and innovativeness, Journal of the academy of marketing science, 34 (2006) No. 1, pp. 63-73

[52] Merrilees, B., Rundle-Thiele, S. and Lye, A.: Marketing capabilities: Antecedents and implications for B2B SME performance, Industrial Marketing Management, 40 (2011) No. 3, pp. 368-375

[53] Mooi, E. and Sarstedt, M.: A concise guide to market research, chapter 9:“Cluster analysis”, Berlin: Springer-Verlag, 10 (2011) pp. 978-973

[54] Morgan, R. M. and Hunt, S. D.: The commitment-trust theory of relationship marketing, The journal of marketing (1994) pp. 20-38

[55] M'zungu, S. D., Merrilees, B. and Miller, D.: Brand management to protect brand equity: A conceptual model, Journal of Brand management, 17 (2010) No. 8, pp. 605-617

[56] Naina Mohamed, R. and Mohd Daud, N.: The impact of religious sensitivity on brand trust, equity and values of fast food industry in Malaysia, Business Strategy Series, 13 (2012) No. 1, pp. 21-30

[57] Nasution, H. N., Mavondo, F. T., Matanda, M. J. and Ndubisi, N. O.: Entrepreneurship: Its relationship with market orientation and learning orientation and as antecedents to innovation and customer value, Industrial marketing management, 40 (2011) No. 3, pp. 336-345

[58] Noble, C. H., Sinha, R. K. and Kumar, A.: Market orientation and alternative strategic orientations: A longitudinal assessment of performance implications, Journal of marketing, 66 (2002) No. 4, pp. 25-39

[59] Piaralal, S. and Mei, T. M.: Determinants of Brand Equity in Private Healthcare Facilities in Klang Valley, Malaysia, American Journal of Economics, 5 (2015) No. 2, pp. 177-182 
[60] Rajaguru, R. and Jekanyika Matanda, M.: Influence of inter-organisational integration on business performance: The mediating role of organisationallevel supply chain functions, Journal of Enterprise Information Management, 22 (2009) No. 4, pp. 456-467

[61] Rosenbusch, N., Brinckmann, J. and Bausch, A.: Is innovation always beneficial? A meta-analysis of the relationship between innovation and performance in SMEs, Journal of business Venturing, 26 (2011) No. 4, pp. 441-457

[62] Santos-Vijande, M. L., del Río-Lanza, A. B., Suárez-Álvarez, L. and DíazMartín, A. M.: The brand management system and service firm competitiveness, Journal of Business Research, 66 (2013) No. 2, pp. 148157

[63] Schindehutte, M., Morris, M. and Allen, J.: Beyond achievement: Entrepreneurship as extreme experience. Small Business Economics, 27 (2006) No. 4-5, pp. 349-368

[64] Seelos, C. and Mair, J.: Innovation is not the Holy Grail, Stanf Soc Innov Rev, 10 (2012) No. 4, pp. 44-49

[65] Seggie, S. H., Kim, D. and Cavusgil, S. T.: Do supply chain IT alignment and supply chain interfirm system integration impact upon brand equity and firm performance?, Journal of business research, 59 (2006) No. 8, pp. 887895

[66] Sexton, D. L. and Smilor, R. W.: Entrepreneurship 2000, Kaplan Publishing, (1997)

[67] Theoharakis, V. and Hooley, G.: Customer orientation and innovativeness: Differing roles in New and Old Europe, International Journal of Research in Marketing, 25 (2008) No. 1, pp. 69-79

[68] Vazquez, R., Del Rio, A. B. \& Iglesias, V.: Consumer-based brand equity: development and validation of a measurement instrument, Journal of Marketing management, 18 (2002) No. 1-2, pp. 27-48

[69] Vorhies, D. W. and Morgan, N. A.: Benchmarking marketing capabilities for sustainable competitive advantage, Journal of marketing, 69 (2005) No. 1, pp. 80-94

[70] Yoo, B., Donthu, N. and Lee, S.: An examination of selected marketing mix elements and brand equity, Journal of the academy of marketing science, 28 (2000) No. 2, pp. 195-211

[71] Zhang, H., Ko, E. and Lee, E.: Moderating Effects of Nationality and Product Category on the Relationship between Innovation and Customer Equity in K orea and China, Journal of Product Innovation Management, 30 (2013) No. 1, pp. 110-122

[72] Zheng, W., Yang, B. and McLean, G. N.: Linking organizational culture, structure, strategy, and organizational effectiveness: Mediating role of knowledge management, Journal of Business research 63 (2010) No. 7, pp. 763-771 